\title{
Vermorste Vleiland: Die teenwoordigheid en ruimtelike verspreiding van plastiekafval in die Fisantekraalvleiland
}

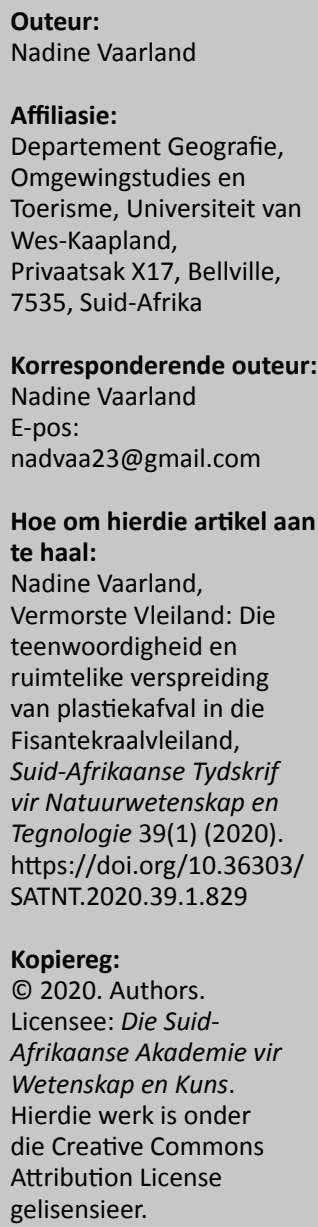

\begin{abstract}
Wasted Wetland: The presence and spatial distribution of plastic waste in the Fisantekraal Wetland: This research was conducted to determine the presence and spatial distribution of macro and meso plastics within a freshwater system. A valley-bottom wetland was used as the study site. Samples of waste were collected where they occurred within the wetland and results showed a widespread distribution of waste from 'food packaging' and 'domestic waste'.
\end{abstract}

Hierdie navorsing fokus op die teenwoordigheid en ruimtelike verspreiding van plastiekafval in die Fisantekraalvleiland in Durbanville, Wes-Kaap. Die vleiland is in 'n stad en naby woongebiede en hoofpaaie geleë. In dieselfde gebied, langsaan die vleiland, is daar ' $n$ koringplaas met plaasdiere.

Oor die afgelope paar jaar is daar ' $n$ toename in die teenwoordigheid van plastiekafval in ons waterstelsels. Die meeste van die bestaande navorsing fokus egter op mikroplastiek in marienestelsels. Dus is daar 'n gebrek aan navorsing oor makroplastiek in varswaterstelsels.

Oor die algemeen bedreig plastiekbesoedeling diere, die omgewing en mense. In vleilande kan die funksies van hierdie stelsels deur plastiek ontwrig word. Dit het ook negatiewe impakte op die inwoners wat van hierdie stelsels afhanklik is. Die hoofdoelstelling van hierdie studie is om die ruimtelike verspreiding en die teenwoordigheid van plastiekafval in ' $n$ valleibodemvleiland te ondersoek. Met hierdie doelstelling is dit belangrik om verder te gaan en die afval in verskillende soorte en groottes te sorteer. Die akkumulasiepatrone van die afval kan dan ondersoek word.

Die studie het afvalmonsters versamel waar dit voorkom. ' $\mathrm{n}$ Radius van $5 \mathrm{~m}$ is rondom elke lokaliteit opgestel en al die afval wat in hierdie gebied voorgekom het, is versamel. Hierdie afval is in sakke geplaas, benoem en hul GPS-koördinate is aangeteken. Die koördinate is dan later in ArcGis gedigitaliseer.

Die resultate van die navorsing wys dat die afval verspreid oor die vleiland voorgekom het en hoofsaaklik in twee kategorieë geskei kan word, naamlik 'Voedselverpakking' en 'Huishoudelike afval'. Tabelle 1 en 2 wys die verskillende tipes afval wat in die vleiland gevind is.

TABEL 1: Aantal voedselverpakkingsmonsters in hul onderskeie kategorieë gesorteer

\begin{tabular}{l|c|c|c|c|c|c|c|c}
\hline $\begin{array}{l}\text { Voedselver- } \\
\text { pakking }\end{array}$ & $\begin{array}{c}\text { Onplaasbaar/ } \\
\text { Ander }\end{array}$ & Inkopiesakke & $\begin{array}{c}\text { Sjokolade- en } \\
\text { lekkergoed- } \\
\text { verpakking }\end{array}$ & Bottels & $\begin{array}{c}\text { Skyfie- } \\
\text { pakkies }\end{array}$ & $\begin{array}{c}\text { Melk- } \\
\text { pakkies }\end{array}$ & $\begin{array}{c}\text { Brood- } \\
\text { pakkies }\end{array}$ & $\begin{array}{c}\text { Totaal } \\
\text { Aantal }\end{array}$ \\
Persentasie & 21 & 5 & 17 & 20 & 25 & 2 & 3 & 93 \\
\hline
\end{tabular}

TABEL 2: Aantal huishoudelike afvalitems gesorteer in hul onderskeie kategorieë

\begin{tabular}{l|c|c|c|c|c|c}
\hline $\begin{array}{l}\text { Huishoudelike } \\
\text { afval: }\end{array}$ & $\begin{array}{c}\text { Plastiek } \\
\text { emmers }\end{array}$ & $\begin{array}{c}\text { Ander } \\
\text { plastieksakke }\end{array}$ & $\begin{array}{c}\text { Polistireen- } \\
\text { houers }\end{array}$ & Swartsakke & Plastiekhouers & Totaal \\
\hline Aantal & $3(5 \mid$ elk) & 21 & 5 & 2 & 8 & 39 \\
Persentasie & $7 \%$ & $54 \%$ & $13 \%$ & $5 \%$ & $21 \%$ & $100 \%$ \\
\hline
\end{tabular}

Nota: 'n Seleksie van referaatopsommings: Studentesimposium in die Natuurwetenskappe, 31 Oktober - 1 November 2019 Universiteit van die Vrystaat. Reëlingskomitee: Prof Rudi Pretorius (Departement Geografie, Universiteit van Suid-Afrika); Dr Hertzog Bisset (Suid-Afrikaanse Kernenergie-korporasie; Dr Ernie Langner (Departement Chemie, Universiteit van die Vrystaat) en Dr Wynand Nel (Departement Rekenaarwetenskap en Informatika, Universiteit van die Vrystaat). 
Uit Tabelle 1 en 2 is dit duidelik dat daar meer items vir voedselverpakking (70\%) as vir huishoudelike afval (30\%) is. Die bron van die afval wat in die vleiland voorkom kan moontlik die inwoners van die nabygeleë woonbuurt wees, afvoerpype vir stormwater, sowel as die gebruikers van die aangrensende pad.

Die resultate van die studie toon dat daar wel 'n behoefte bestaan vir navorsing oor makroplastiek en plastiek in die algemeen in varswaterstelsels. Mikroplastiek word gevorm deur die afbreking van groter plastiekitems en varswaterstelsels kan hierdie afval na marienestelsels vervoer. Plastiekafval is ' $\mathrm{n}$ groot omgewingsprobleem en benodig deeglike navorsing en bestuurstrategieë om die probleem te verminder en dit te kan oplos. 